\title{
Medical Women on Planet Venus
}

\author{
Usha Saraiya
}

\begin{abstract}
There are 13 medical women who have graced the craters on Planet Venus by virtue of their contribution to medical science. Out of these, two from each of Germany and India and one from each of nine countries, namely, Iran, Greece, Italy, Spain, France, Britain, Russia, China, and Japan.

This presentation will review the biographies of all of them. There are seven who lived and worked in the 19th and 20th centuries. Needless to say, they all have made outstanding contributions to medical relief. Venus has about 1,000 craters identified on its surface.

Venus is supposed to be the planet for women. It is known as a twin of Earth as it is of the same mass and size as Earth.

In 1991, scientists studying Venus with Magellan spacecraft proposed that these craters be named after famous women. It is an "Honor" for a positive contribution to medical science and society.

There have been many space missions to study Venus. The then USSR sent 30 Venera Missions to Venus starting in 1961. Currently, a Japanese Akatsuki spaceship is orbiting Venus.

Medical women had a late entry into medical profession, some time in the mid-19th century. They were not welcomed and had to establish themselves against all odds. In a span of 100 years, women in medicine gained a strong foothold and their contribution to health care was acknowledged all over the world. By the end of 20th century, their life and works were immortalized on Planet Venus. The history of the development of women in medical profession is chronicled here.

It is a proud moment for all medical doctors that so many grace the craters of Planet Venus.

Keywords: Doctors, Gynecology, Planet Venus Medical Women Craters named after, Woman.

Journal of South Asian Federation of Obstetrics and Gynaecology (2021): 10.5005/jp-journals-10006-1900
\end{abstract}

\section{INTRODUCTION}

It is interesting to note that there are 13 women doctors who have graced the craters on Planet Venus by virtue of their contribution to medical science. Out of these, two from each of Germany and India and one from each of nine countries, namely, Iran, Greece, Italy, Spain, France, Britain, Russia, China, and Japan.

\section{Material and Methods}

This presentation will review the biographies of all of them. There are seven who lived and worked in the 19th and 20th centuries. Needless to say, they all have made outstanding contributions to medical relief and therefore deserve to be immortalized on Planet Venus.

When you look at the Moon or Mercury, their surfaces are pounded with impact craters. Mars has many craters and so does Earth. Venus has about 1,000 craters identified on its surface. ${ }^{1}$ Only about 100 craters have been identified and named so far.

Venus is supposed to be the planet for women, and Mars is supposed to be planet for men. Venus is a Goddess of love, beauty, and fertility in Greek mythology. This planet is 4.6 billion years old. The first person to point a telescope at Venus was Galileo Galilei in 1618. It is known as a twin of Earth as it is of the same mass and size as Earth. It is Earth's neighbor on the side of the sun. ${ }^{2}$

In 1991, scientists studying Venus with Magellan spacecraft (Figs 1 and 2) proposed that these craters be named after famous
Consulting Gynecologist, Dr. Usha Saraiya Clinic, 203 Doctor Center, AK Marg, Mumbai, Maharashtra, India

Corresponding Author: Usha Saraiya, Consulting Gynecologist, Dr. Usha Saraiya Clinic, 203 Doctor Center, AK Marg, Mumbai, Maharashtra, India, Phone: +919820059050, e-mail: ushasaraiya@hotmail.com

How to cite this article: Saraiya U. Medical Women on Planet Venus. J South Asian Feder Obst Gynae 2021;13(3):185-190.

Source of support: Nil

Conflict of interest: None

women. ${ }^{3}$ Instead of giving them numbers, it was decided to give eponyms. Oxford English Dictionary defines eponym as "A person after whom a discovery, invention, place, etc. is named or thought to be named." In medicine, there are over 15,000 eponyms. It is an "Honor" for a positive contribution to the medical science in the relevant endeavor. Each crater has its own location or coordinates and diameter recorded. The year the eponym was approved is also recorded. The International Astronomical Union approved this proposal.

Since then, about 100 craters have been named. The famous women after whom craters are named include playwright Lillian Hellman and Clare Booth Luce. Margaret Mead, the anthropologist, and Pearl Buck, the famous author, also feature in the list. Among them, there are 13 women doctors.

() Jaypee Brothers Medical Publishers. 2021 Open Access This article is distributed under the terms of the Creative Commons Attribution 4.0 International License (https://creativecommons.org/licenses/by-nc/4.0/), which permits unrestricted use, distribution, and non-commercial reproduction in any medium, provided you give appropriate credit to the original author(s) and the source, provide a link to the Creative Commons license, and indicate if changes were made. The Creative Commons Public Domain Dedication waiver (http://creativecommons.org/publicdomain/zero/1.0/) applies to the data made available in this article, unless otherwise stated. 


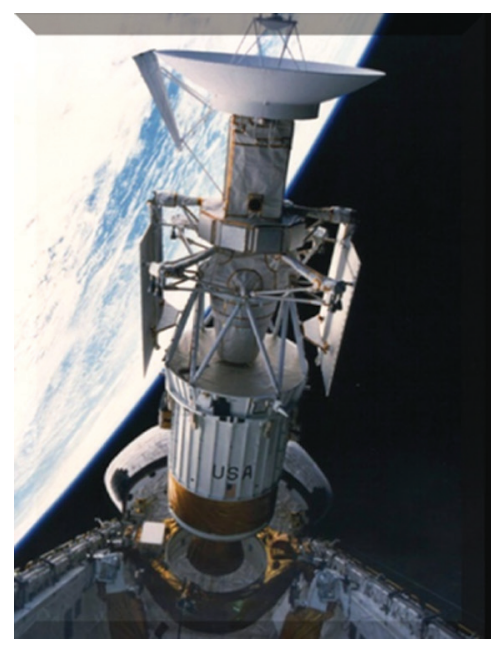

Fig. 1: Magellan Spaceship to Venus. Image Credit: NASA. Last updated: August 7, 2017; Editor: NASA Content Administrator ${ }^{5}$

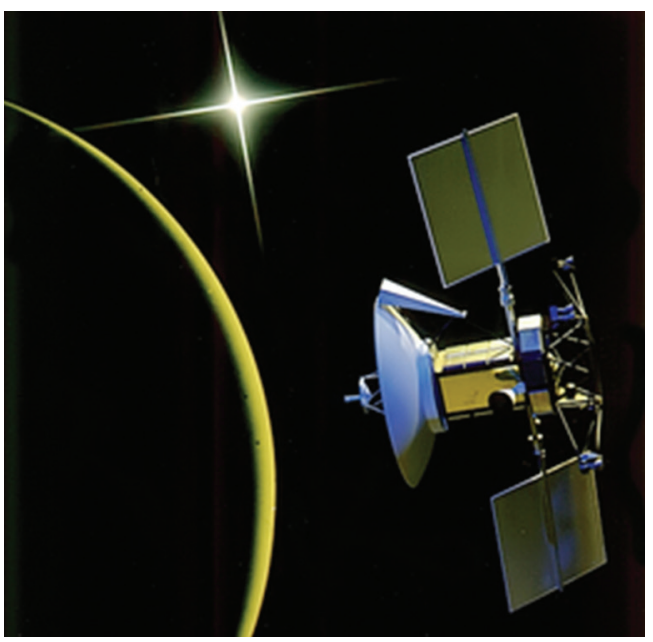

Fig. 2: Artist's depiction of Magellan at Venus. Available from: https:// en.wikipedia.org/wiki/Magellan_(spacecraft) ${ }^{5}$

\section{Results}

Table below gives the details of all the craters named after women doctors. Each crater has a name, its location, diameter, and the year it was named.

\begin{tabular}{|c|c|c|c|c|c|}
\hline SI. Nos. & Crater & Coordinates & Diameter (km) & Approval year & Eponym \\
\hline 1 & Andami & $17.5^{\circ} \mathrm{S} 26.5^{\circ} \mathrm{E}$ & 28.9 & 1991 & AzarAndami, Iranian physician and researcher \\
\hline 2 & Anicia & $26.3^{\circ} \mathrm{S} 31.3^{\circ} \mathrm{E}$ & 38.2 & 1991 & Anicia, Ancient Greek physician and poet \\
\hline 3 & Cortes & $11.4^{\circ} \mathrm{S} 141.6^{\circ} \mathrm{W}$ & 27.7 & 1994 & Isabella Cortese, Italian physician \\
\hline 4 & Erxleben & $50.9^{\circ} \mathrm{S} 39.4^{\circ} \mathrm{E}$ & 31.6 & 1991 & Dorothea Christiane Erxleben, German physician \\
\hline 5 & Galindo & $23.3^{\circ} \mathrm{S} 101.2^{\circ} \mathrm{W}$ & 23.8 & 1994 & Beatrix Galindo, Spanish physician and educator \\
\hline 6 & Heloise & $40^{\circ} \mathrm{N} 51.9^{\circ} \mathrm{E}$ & 38 & 1994 & Heloise, French physician \\
\hline 7 & Jex-Blake & $65.4^{\circ} \mathrm{N} 169.3^{\circ} \mathrm{E}$ & 31.6 & 1991 & $\begin{array}{l}\text { Sophia Jex-Blake, British pioneer woman physician } \\
(1840-1912)\end{array}$ \\
\hline 8 & Jhirad & $16.8^{\circ} \mathrm{S} 105.6^{\circ} \mathrm{E}$ & 50.2 & 1994 & $\begin{array}{l}\text { Jerusha https://en.wikipedia.org/wiki/Jerusha } \\
\text { Jhirad (1891-1984), Indian physician. }\end{array}$ \\
\hline 9 & Joshee & $5.5^{\circ} \mathrm{N} 71.3^{\circ} \mathrm{W}$ & 37 & 1994 & $\begin{array}{l}\text { Anandibai Joshee, Indian pioneer physician } \\
(1865-1887) \text {. }\end{array}$ \\
\hline 10 & Rudneva & $78.4^{\circ} \mathrm{N} 174.7^{\circ} \mathrm{E}$ & 29.8 & 1985 & Varvara Rudneva, Russian physician (1844-1899). \\
\hline 11 & Shih Mai-Yu & $18.4^{\circ} \mathrm{N} 41.1^{\circ} \mathrm{W}$ & 22.3 & 1994 & Shih Mai-Yu Chinese physician (1873-1954). \\
\hline 12 & Von Siebold & $52^{\circ} \mathrm{S} 36.6^{\circ} \mathrm{E}$ & 32.4 & 1991 & $\begin{array}{l}\text { Regina von Siebold, German physician, educator } \\
(1771-1849) .\end{array}$ \\
\hline 13 & Yoshioka Yayoi & $32.4^{\circ} \mathrm{S} 59^{\circ} \mathrm{E}$ & 16.6 & 1994 & $\begin{array}{l}\text { Yoshioka Yayoi Japanese physician, College founder } \\
\text { (c. 1871-1959) }\end{array}$ \\
\hline
\end{tabular}




\section{Discussion}

The following are the biographies and life sketches of the famous women doctors.

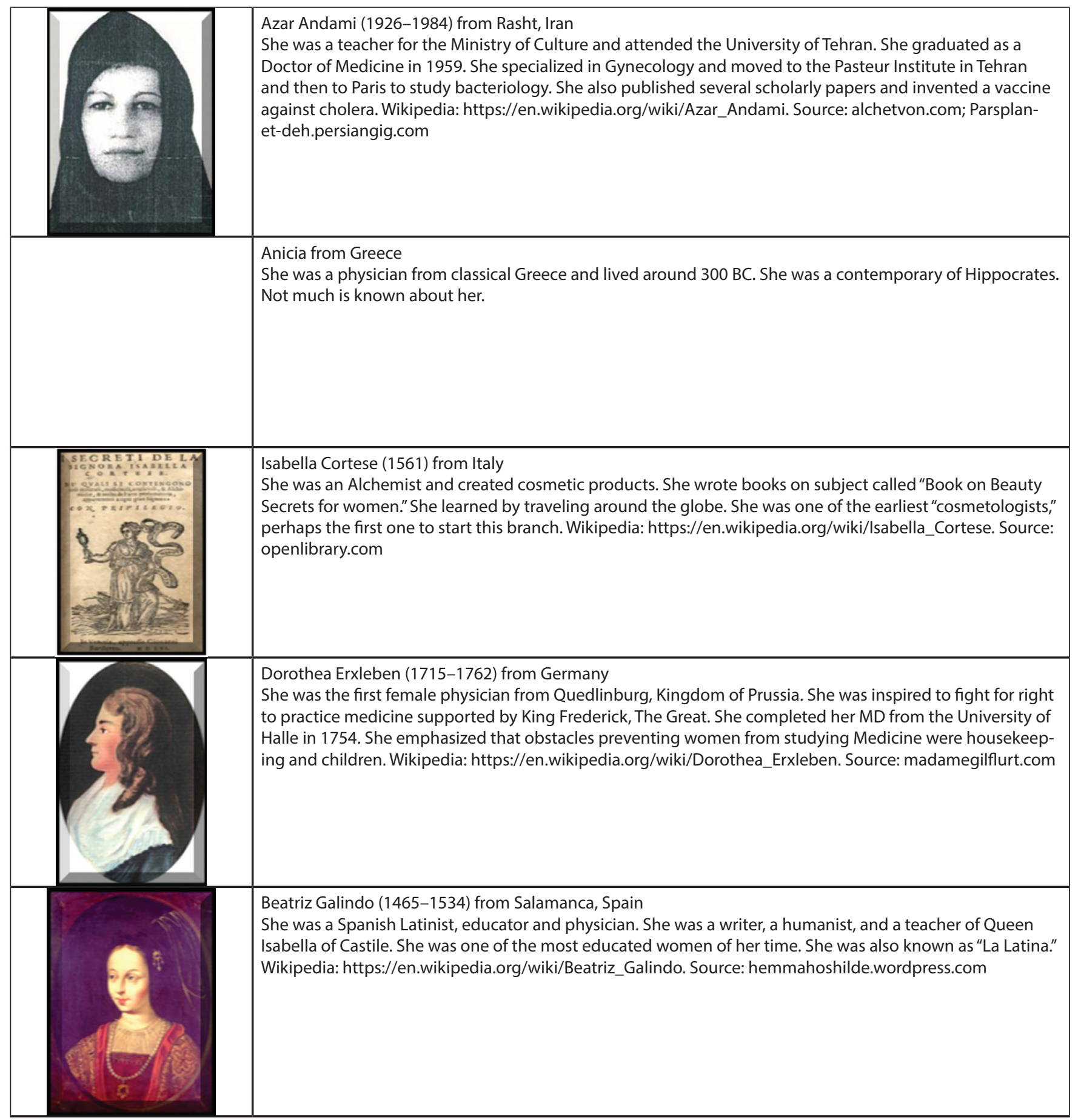




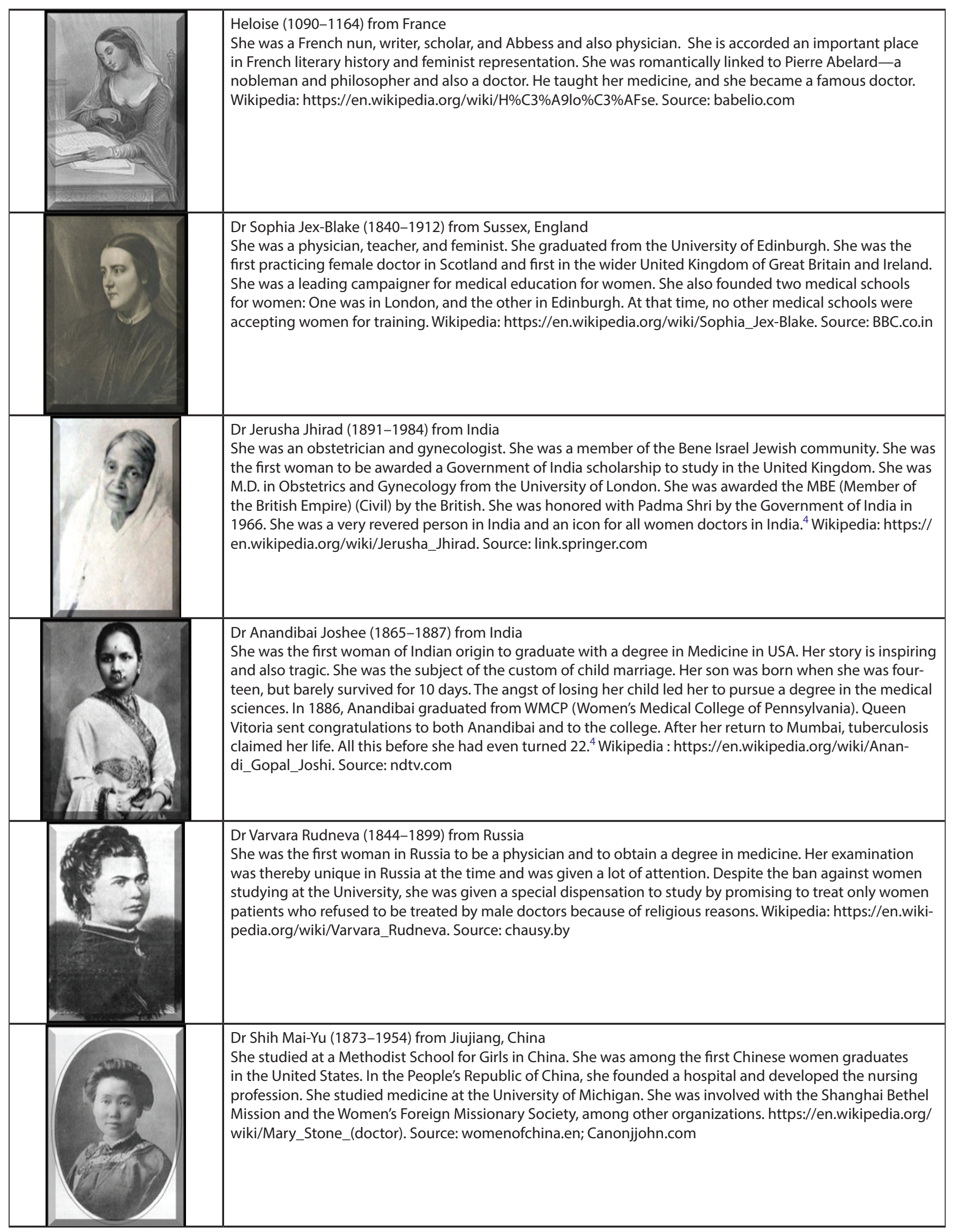




Dr Regina Von Siebold (1771-1849) from Germany
Ragina was the first female obstetrician with University degree. She was married and widowed twice. She
worked as an assistant to her second husband Dr Siebold. She obtained obstetrician license in 1809 from
Darmstadt University and Honorary degree from Giessen University in 1815. Later, her daughter joined her in
medical practice. Wikipedia: https://en.wikipedia.org/wiki/Regina_von_Siebold. Source: helenrappapnt.com

\section{Conclusion}

Women had a very late "entrée" into the medical profession. They were not only not welcomed but were ridiculed when they tried to join the men in the medical college.

They were, however, welcomed into the nursing profession and as Midwives. Florence Nightingale is credited with starting the nursing profession and giving it a good status.

Midwives have always been traditional birth attendants and are still giving service in almost all parts of the world. They have contributed immensely to the reduction of maternal mortality universally. Moreover, it is a well-organized respected profession with opportunities for further training in most countries.

Medical women or women doctors entered the medical profession in the late 19th century. It is not difficult to understand because at that time women were not given a vote. Education itself was not encouraged fully for young girls. Marriage and child bearing was considered as the way forward.

Before the 19th century, there were a few women doctors as can be seen in this study. They were mostly assistants to famous doctors or came from doctor families. They became popular and their services were appreciated. Some appealed to the kings or queens and were given special permission to practice. Occasionally, they received an official medical degree (Dorothea Erxleben in the 18th century).

In 1850, in USA, Quakers set up the Women's Medical College of Pennsylvania in Germantown. It produced a native American woman doctor, Susan La Flesche. Some African American students also got admission. One of them was Eliza Grier, a former slave girl.

It attracted international students consisting of women who were not allowed to study medicine in their own countries. This included three famous women, namely, Anandibai Joshee from India, Keiko Okami of Japan, and Sabat Islambouli of Syria. Each of them became the first qualified woman doctor in their own country. WMCP still exists as a well-known institute for medical women.
Queen Victoria was the reigning Queen of the British Empire in the 19th century. She was crowned as Empress of India. She was aware about the difficulties that women faced in healthcare and that childbirth was itself the major cause of death for women. The struggle to enter medical college had started in UK during her reign.

The London School of Medicine for women was established in 1874. It was perhaps the first to enroll women.

Sophia Jex Blake became the first practicing doctor in United Kingdom. Later she herself founded two medical schools, namely, one in Edinburg and one in London exclusively for women.

It was Queen Victoria who sent two women doctors from UK to Mumbai, India, in 1885 to set up a hospital for women. The Cama and Albless Hospital opened in 1886 and still stands today as a Heritage Institute. ${ }^{4}$

In 1885, the gates of Grant Medical College in Mumbai opened for women. It was established in 1845 and admitted only men till 1885. Five brave women joined, qualified, and started practicing.

Elizabeth Blackwell (1821-1910) was the first American woman doctor to qualify after overcoming many difficulties. She was not accepted into any medical college in USA, despite good qualifications. Finally, she had to go to Geneva Medical College from which she graduated in 1845 . She and her sister practiced for many years in New York and served the under-privileged population.

Australia's first woman doctor was Dr Vivian Violet Cooper (1861-1947) who graduated from London School of Medicine for women in 1886 and emigrated to Australia to become the first female medical doctor in Queensland.

In Japan, Ginko Ogino (1851-1913) was the first woman doctor. Women were not allowed to take the national examination, and she struggled for 15 years and finally got the permission. Thereafter, she worked to establish the position of medical women. In 1902, the Japan Medical Women's Association was formed, which was the very first such association. Yoshioka Yayoi, the first president, has a crater named after her on Planet Venus.

It is therefore very creditable that from this difficult beginning within 100 years women excelled in medicine and were honored 
by having craters in Venus named after them. Thirteen percent of craters are named after women doctors, while others are from the world of arts, literature, and other subjects.

\section{Clinical Significance}

It is a proud moment for all medical doctors that so many grace the craters of Planet Venus. It is a tremendous tribute to their contribution to Humanity on Planet Earth.

This commendable progress needs to be recognized, honored, and widely publicized to serve as an inspiration. That is the overall goal, conclusion and clinical significance of this presentation.

As science advances, more craters will be identified and named. Many more medical women may get honored. There are already many medical women working in NASA and other National Space Organization and are making valuable contributions. We must all feel very proud of their achievements and wish them good luck as they explore the "outer space."

\section{OrCID}

Usha Saraiya ๑ https://orcid.org/0000-0002-2941-355X

\section{References}

1. Fraser Cain. 2008, Updated 2015. Available from: https://www. universetoday.com/22521/craters-on-venus/.

2. Madhumathi DS. After Mars, ISRO turns eye on Venus. The Hindu; April 2017. Available from: https://www.thehindu.com/news/ cities/bangalore/after-mars-isro-turns-eye-on-venus/article 18161738.ece.

3. The New York Times. Available from: https://www.nytimes. com/1991/02/22/us/venus-s-craters-may-be-named-for-women html.

4. Saraiya UB. The firsts-life sketches of medical women in India. Association of medical women in India to commemorate the century (1907-2007); 2006.

5. Photo of Magellan Spaceship to Venus. Available from: https:// en.wikipedia.org/wiki/Magellan_(spacecraft). 